\title{
Rancang Bangun Sistem Informasi Koperasi Berbasis Web Pada Koperasi Ikitama Jakarta
}

\author{
Kurniawan Prasetyo ${ }^{1}$, Suharyanto ${ }^{2}$ \\ ${ }^{1}$ STMIK Nusa Mandiri \\ e-mail: kurniawan.prasetyo@live.com \\ ${ }^{2}$ Sistem Informasi,Universitas Bina Sarana Informatika \\ e-mail: suharyanto@bsi.ac.id
}

Cara Sitasi: Prasetyo, K., \& Suharyanto, S. (2019). Rancang Bangun Sistem Informasi Koperasi Berbasis Web Pada Koperasi Ikitama Jakarta. Jurnal Teknik Komputer, 119-126. doi:10.31294/jtk.v4i2

\begin{abstract}
PT Indolife Pensiontama is a life insurance and pension fund corporation. IKITAMA Cooperation which is acronym of Indolife Pensiontama Employee Association Cooperation is a cooperation organization that having all permanent and active employees as members, in a routin activity IKITAMA Cooperative management manage daily transactions by manual using Microsoft Excel. If there is a new employee or not employed anymore then the record will be updated manually, and also there is no integration with existing human resource system, and all the data saved in Excel File without detail information. With all these problems so the author purpose to make a design and development of web-based cooperation information system. The design using object analytics oriented method by Unified Modeling Language (UML), C\# .Net programming language with Microsoft Visual Studio 2012 as text editor and compiler and Microsoft SQL Server for the Database system.
\end{abstract}

Keywords: Information System, Cooperation, IKITAMA.

\section{PENDAHULUAN}

Koperasi IKITAMA yang merupakan singkatan dari Koperasi Ikatan Karyawan Indolife Pensiontama adalah sebuah organisasi berbadan hukum yang tercantum dalam Keputusan Menteri Koperasi, Pengusaha Kecil dan Menengah Republik Indonesia Nomor: $\quad$ 082/BH/KDK.9.1/VII/1999. Koperasi IKITAMA beranggotakan semua karyawan tetap PT. Indolife Pensiontama yang masih aktif. PT. Indolife Pensiontama adalah sebuah perusahaan yang bergerak di bidang asuransi jiwa dan dana pensiun, memulai bisnisnya pada tahun 1991. Dalam pengelolaanya pengurus Koperasi IKITAMA melakukan pembukuan secara manual menggunakan Excel, jika ada karyawan yang baru masuk ataupun karyawan yang keluar maka pencatatannya di update secara manual, karena belum terintegrasi dengan sistem informasi SDM yang ada, dan data yang terdapat di dalam file Excel hanya berupa summary pinjaman dan simpanan setiap karyawan. Tidak jarang terjadi kesalahan dalam pengelolaan datanya terutama apabila ada karyawan yang keluar, penambahan simpanan, atau yang melakukan perubahan skema pinjaman.

Menurut Suharyanto (2017:139) dalam Jurnal Ilmu Pengetahuan Dan Teknologi Komputer, organisasi yang menginginkan kelancaran dalam pengoperasian kegiatan perusahaannya dapat memanfaatkan teknologi informasi dan komunikasi sebagai sarana yang tepat digunakan untuk memenuhi hal tersebut diatas. Diantara teknologi informasi dan komunikasi yang saat ini banyak digunakan adalah teknologi berbasis web. Berdasarkan permasalahan yang telah dipaparkan maka diperlukan sistem informasi yang dapat diandalkan oleh pengurus Koperasi IKITAMA dalam pengelolaan data informasi koperasi agar tidak ada lagi kesalahan dalam pelaporan datanya, karena laporan data dari koperasi akan menentukan potongan gaji karyawan setiap bulannya.

Pasal 1 ayat (1) Undang-Undang No.25 tahun 1992 tentang perkoperasian adalah suatu badan usaha yang beranggotakan orang-orang atau badan hukum koperasi dengan berlandaskan kegiatannya berdasar prinsip-prinsip koperasi. Di dalam Undang-Undang No.25 tahun 1992 Pasal 22 menyatakan bahwa rapat anggota merupakan kekuasaan tertinggi dalam koperasi. Dalam tujuan tersebut dapat dimengerti bahwa koperasi merupakan salah satu badan usaha, disamping badan usaha lain seperti BUMN, BUMD, maupun badan usaha swasta seperti Perseroan Terbatas, CV, UD, dan lainnya. Koperasi merupakan badan usaha yang lebih dekat dengan rakyat, dan bahkan koperasi merupakan badan usaha yang sangat demokratis, karena koperasi dibentuk oleh anggota dan berazaskan kekeluargaan (Winarko, 2014:152) 


\section{METODOLOGI PENELITIAN}

Metode penelitian merupakan suatu cara bagaimana seorang penulis dapat memahami suatu pembahasan permasalahan dan pemecahan masalah didalam sebuah sistem informasi koperasi, maka penulis menggunakan beberapa metode, sebagai berikut :

1. Teknik Pengumpulan Data

Teknik pengumpulan data dilakukan dengan beberapa tahap pencarian yaitu:

\section{a. Observasi}

Dalam metode ini penulis secara langsung mengumpulkan data dengan melakukan pengamatan secara langsung kegiatan pengurus Koperasi IKITAMA Jakarta untuk mengetahui masalah yang terjadi dalam sistem berjalan.

\section{b. Wawancara}

Teknik pengumpulan data dengan mengadakan tanya jawab langsung kepada terkait dengan pembahasan yang diambil.

\section{c. Studi Pustaka}

Dalam metode ini penulis mengumpulkan data dengan membaca, serta memahami permasalahan yang terkait melalui buku-buku, internet, dan jurnal.

\section{Model Pengembangan Sistem}

Metode yang digunakan dalam mengembangkan sistem informasi koperasi berbasis web adalah waterfall. Menurut Sukamto \& Shalahuddin (2016:28-31), Model SDLC (Software Development Life Cycle) air terjun (waterfall) sering juga disebut model sekuensial linier (sequential linear) atau alur hidup klasik (classic life cycle).

Menurut Rossa dan Shalahuddin dalam Larasati dan Masripah (2017:194) pada Jurnal Pilar Nusa Mandiri, SDLC atau Software Development Life Cycle atau sering disebut juga System Development Life Cycle adalah proses mengembangkan atau mengubah suatu sistem perangkat lunak dengan menggunakan modelmodel dan metodologi yang digunakan orang untuk mengembangkan sistem-sistem perangkat lunak sebelumnya (berdasarkan best practice atau cara-cara yang sudah teruji baik). Model air terjun menyediakan pendekatan alur hidup perangkat lunak secara sekuensial atau terurut dimulai dari analisis desain, pengkodean, pengujian, dan tahap pendukung (support).

Menurut Rosa dan Shalahuddin dalam Larasati dan Masripah (2017:194), Model SDLC air terjun (waterfall) sering juga disebut model sekuensial linier (sequential linear) atau alur hidup klasik (classic life cycle). Model air terjun menyediakan pendekatan alur hidup perangkat lunak secara sekuensial atau terurut dimuali dari analisis desain, pengkodean, pengujian, dan tahap pendukung (support). Berikut adalah gambar model air tejun:

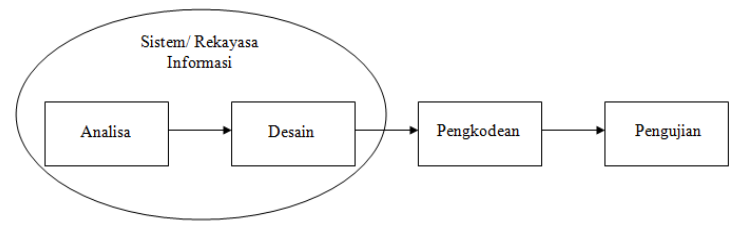

Sumber : Rosa dan Shalahuddin (2016:31)

Gambar 1. Model Waterfall

Berikut adalah tahapan-tahapan pada waterfall :

a. Analisa Kebutuhan Software

Penulis menganalisa kebutuhan apa saja yang dibutuhkan dalam pembuatan sistem informasi koperasi berbasis web menggunakan model waterfall, diantaranya bentuk dokumen masukan (kategori barang, data barang, data customer, dokumen keluaran (laporan-laporan).

b. Desain

Penulis melakukan perancangan sistem informasi koperasi berbasis web meliputi desain sistem menggunakan UML (Activity Diagram, Use Case Diagram, Component Diagram, Deployment Diagram) untuk desain database menggunakan ERD.

c. Code Generation

Di tahap ini penulis menggunakan bahasa pemograman C\# .Net dan database SQL Server, sedangkan representasi interface menggunakan Microsoft Visual Studio 2012 dalam pembuatan sistem informasi koperasi berbasis web. Sistem yang dibangun termasuk kedalam pemograman terstruktur.

d. Testing

Pembuatan program membutuhkan uji coba sebelum di publikasikan. Kali ini penulis menggunakan blackbox Testing untuk menguji form login, form data admin, form data customer, form kategori barang, form laporan, dan form transaksi. Uji coba blackbox berusaha untuk menemukan kesalahan dalam beberapa kategori, diantaranya fungsi-fungsi yang salah atau hilang, kesalahan pada interface, kesalahan dalam struktur data atau akses database eksternal, kesalahan inisialisasi dan terminasi.

e. Support

Dalam mendukung sistem informasi yang akan 
dikerjakan diperlukan perangkat keras (hardware) yaitu peralatan dalam bentuk fisik yang menjalankan perangkat lunak (software) dan peralatan ini berfungsi untuk menjalankan instruksi yang diberikan dan mengeluarkannya dalam bentuk informasi.

\section{HASIL DAN PEMBAHASAN}

1. Analisa Kebutuhan

Analisa kebutuhan merupakan langkah awal yang dilakukan agar didapat gambaran dari sebuah sistem yang akan dibuat. Berikut rincian pembagian halaman berdasarkan level pengguna:

a. Halaman Anggota :

- Anggota dapat melihat halaman beranda.

- Anggota dapat melihat halaman pengajuan simpanan.

- Anggota dapat melihat halaman pengajuan pinjaman.

b. Halaman Sekretaris I:

- Sekretaris I dapat melihat halaman beranda.

- Sekretaris I dapat mengelola data keanggotaan koperasi.

- Sekretaris I dapat mengelola data simpanan.

- Sekretaris I dapat mengelola data pinjaman.

- Sekretaris I dapat melihat dan mencetak semua halaman laporan.

- Sekretaris I dapat mengelola pengajuan Anggota.

c. Halaman Sekretaris II:

- Sekretaris II dapat melihat halaman beranda.

- Sekretaris II dapat melihat halaman data keanggotaan koperasi.

- Sekretaris II dapat melihat data simpanan.

- Sekretaris II dapat melihat data pinjaman.

- Sekretaris II dapat melihat dan mencetak semua halaman laporan.

d. Halaman Bendahara :

- Bendahara dapat melihat halaman beranda

- Bendahara dapat melihat halaman keanggotaan

- Bendahara dapat melihat halaman simpanan

- Bendahara dapat melihat halaman pinjaman

- Bendahara dapat melihat semua halaman.

e. Halaman User Admin:

- Admin dapat melihat halaman beranda.

- Admin dapat mengelola data user aplikasi.

- Admin dapat melihat data Audit Trail/User Log.

2. Desain

a. Desain Basisdata

1. Entity Relationship Diagram
Dalam pengembangan database penulis menggunakan ERD dan LRS, Menurut Brady dan Loonam dalam Puspitasari (2016:188) dalam Jurnal Pilar Nusa Mandiri, Entity Relationship Diagram (ERD) merupakan teknik yang digunakan untuk memodelkan kebutuhan data dari suatu organisasi, biasanya oleh analis sistem dalam tahap analisis persyaratan proyek pengembangan sistem.

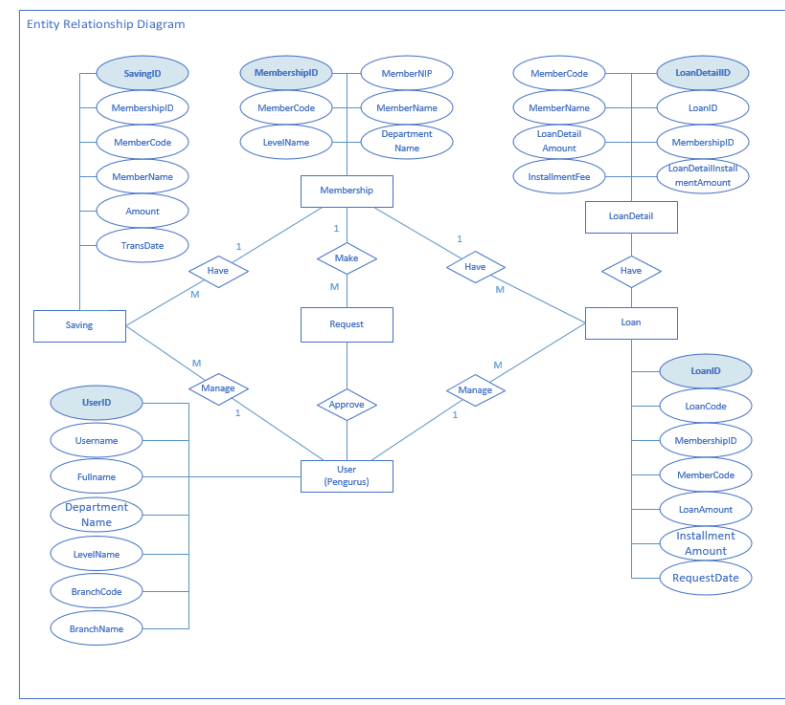

Gambar 2. Entity Relationship Diagram

\section{Logical Record Structure}

Menurut Hasugian dan Shidiq dalam Larasati dan Masripah (2017:194-195), memberikan batasan bahwa Logical Record Structure (LRS) adalah sebuah model sistem yang digambarkan dengan sebuah diagram-ER akan mengikuti pola atau aturan permodelan tertentu dalam kaitannya dengan konvensi ke LRS.

Dalam pembuatan LRS terdapat tiga hal yang dapat mempengaruhi, yaitu:

- Jika tingkat hubungan (cardinality) satu pada satu (one-to-one), maka digabungkan dengan entitas yang lebih kuat (strong entity), atau digabungkan dengan entitas yang memiliki atribut yang lebih sedikit.

- Jika tingkat hubungan (cardinality) satu pada banyak (one-to-many), maka hubungan relasi atau digabungkan dengan entitas yang tingkat hubungannya banyak. 


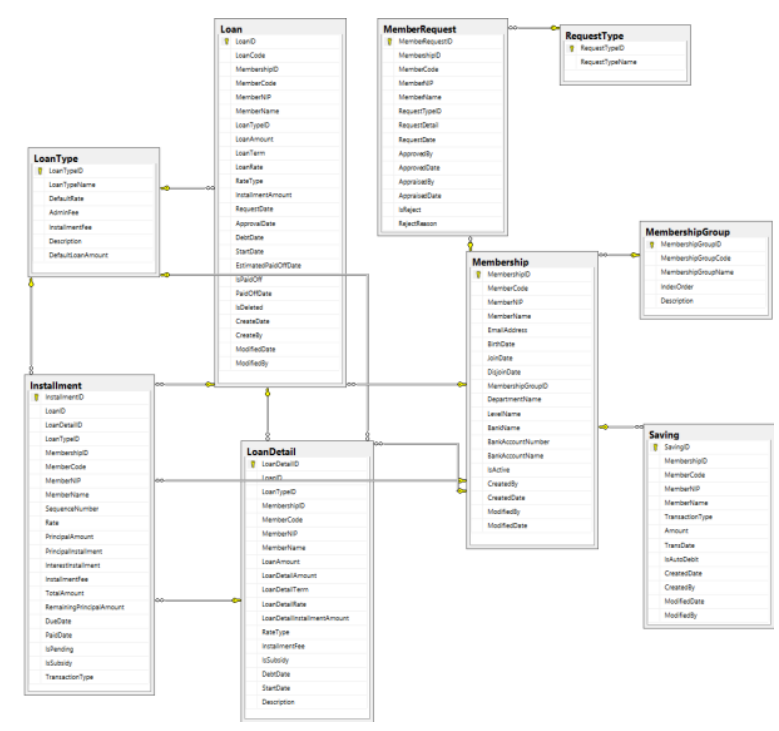

Gambar 3. Logical Record Structure

\section{Use Case Diagram.}

Use Case diagram menggambarkan interaksi pengguna atau aktor terhadap system. Berikut ini desain rancangan use case diagram Halaman anggota.

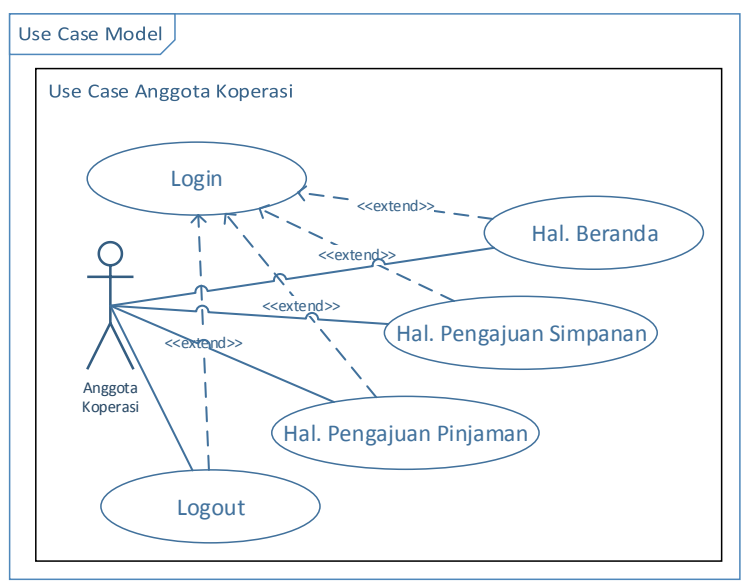

Gambar 4. Use Case Diagram Halaman Anggota

Deskripsi Use Case Diagram Halaman Anggota :

Tabel 1. Deskripsi Use Case Diagram Halaman Anggota

\begin{tabular}{ll}
\hline Use Case Name & Anggota \\
\hline Requirements & A1-A3 \\
\hline Goal & $\begin{array}{l}\text { Anggota Koperasi dapat } \\
\text { melihat halaman beranda, } \\
\text { halaman pengajuan simpanan, } \\
\text { halaman pengajuan pinjaman. }\end{array}$ \\
\hline Pre-Conditions & $\begin{array}{l}\text { Anggota Koperasi melakukan } \\
\text { login }\end{array}$ \\
\hline
\end{tabular}

\begin{tabular}{|c|c|}
\hline Post-Conditions & $\begin{array}{l}\text { Anggota Koperasi melakukan } \\
\text { pengajuan pinjaman atau } \\
\text { simpanan. }\end{array}$ \\
\hline $\begin{array}{l}\text { Failed } \\
\text { condition }\end{array}$ & $\begin{array}{l}\text { Gagal mengajukan pinjaman } \\
\text { atau simpanan, pembatalan } \\
\text { pengajuan pinjaman atau } \\
\text { simpanan. }\end{array}$ \\
\hline Primary Actors & Anggota Koperasi \\
\hline \multirow[t]{3}{*}{$\begin{array}{l}\text { Main Flow } \\
\text { Basic patch }\end{array}$} & $\begin{array}{l}\text { 1. Anggota dapat } \\
\text { melihat halaman } \\
\text { beranda }\end{array}$ \\
\hline & $\begin{array}{l}\text { 2. Anggota dapat } \\
\text { melihat halaman } \\
\text { simpanan }\end{array}$ \\
\hline & $\begin{array}{l}\text { 3. Anggota dapat } \\
\text { melihat halaman } \\
\text { pinjaman }\end{array}$ \\
\hline Invariant $A$ & $\begin{array}{l}\text { 1. Anggota dapat } \\
\text { membatalkan } \\
\text { pengajuan. } \\
\text { 2. Anggota dapat } \\
\text { melihat status } \\
\text { pengajuan. }\end{array}$ \\
\hline
\end{tabular}

4. Activity Diagram.

Berikut merupakan gambaran dari berbagai alur aktivitas, pilihan tindakan, perulangan, dan hasil dari aktivitas yang dilakukan dalam sistem yang sedang dirancang. Berikut ini gambaran activity diagram Sistem Informasi IKITAMA..

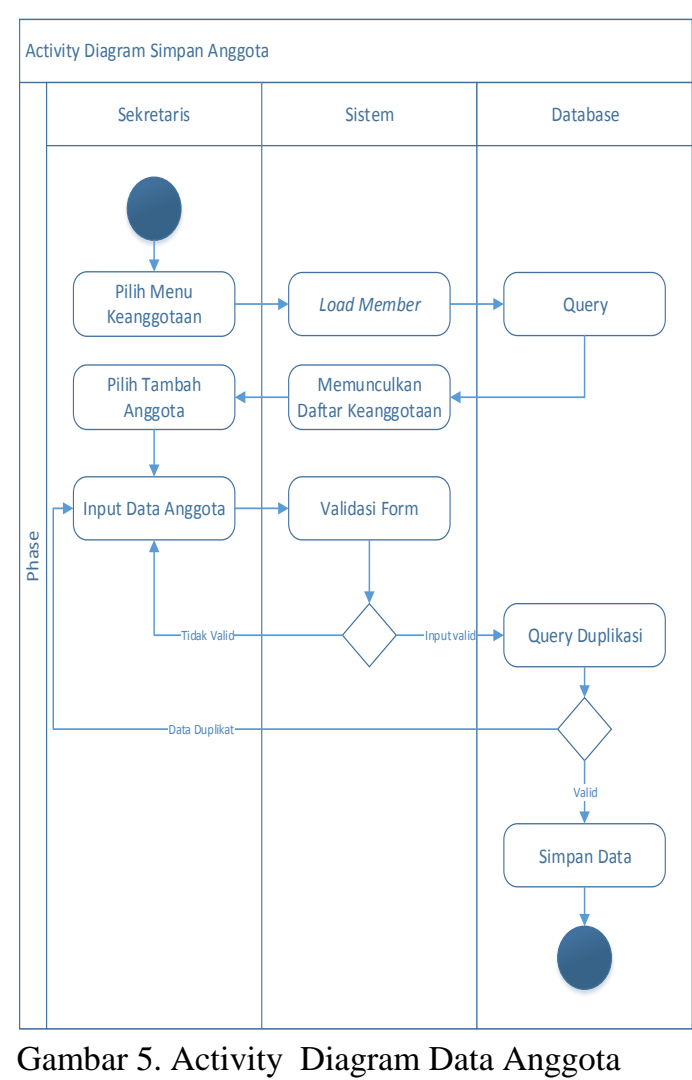


Gambar 9. Tampilan Edit Saving

b. Desain Halaman Antarmuka

1. Halaman Login

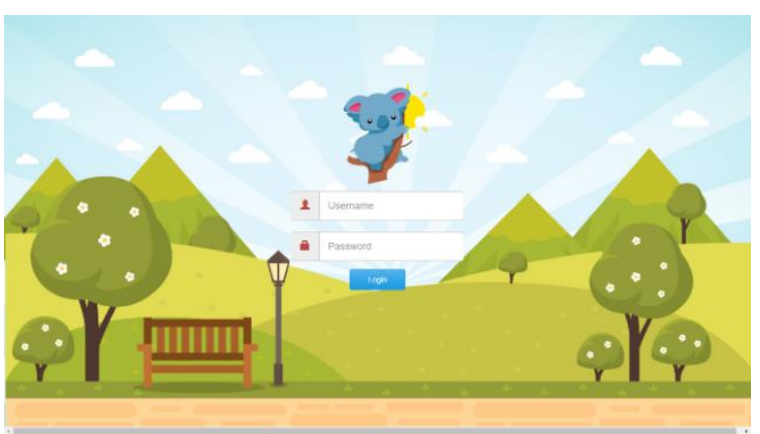

Gambar 6. Tampilan Halaman Login

2. Halaman Beranda

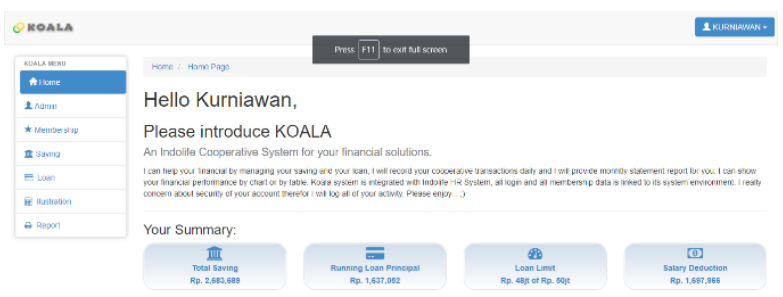

Gambar 7. Tampilan Halaman Beranda

3. Halaman Saving

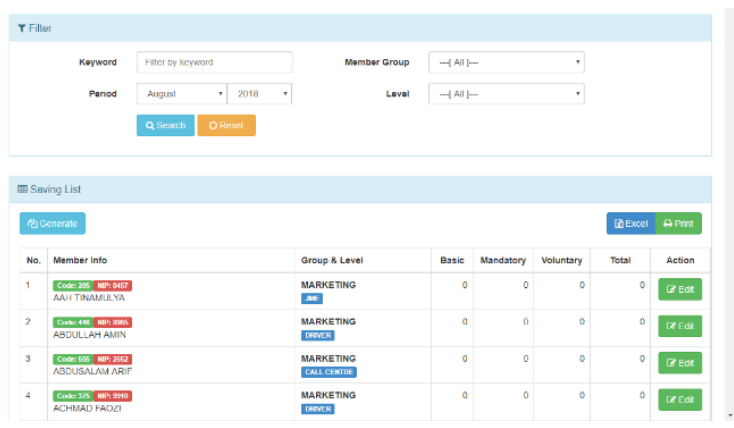

Gambar 8. Tampilan Halaman Saving

4. Tampilan Edit Saving

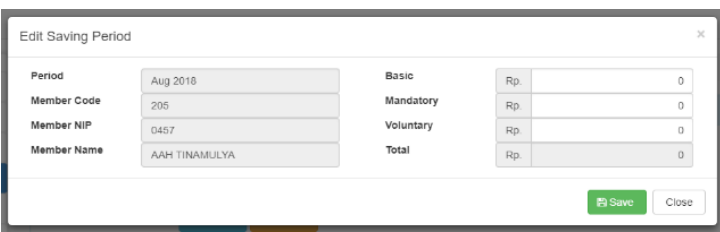

5. Halaman List Loan

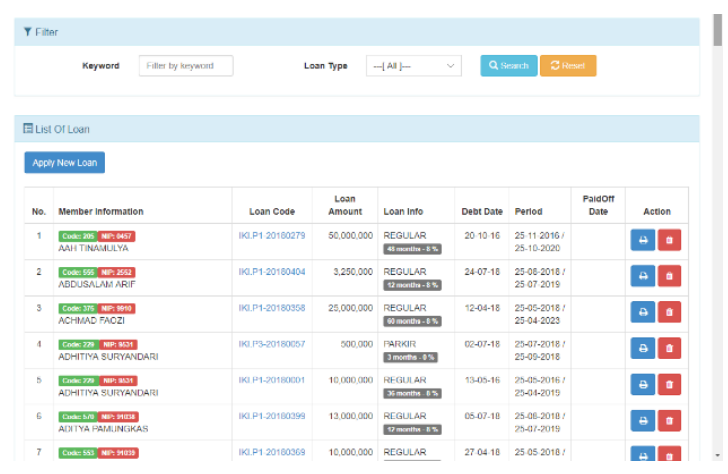

Gambar 10. Tampilan Halaman List Loan

6. Halaman Apply New Loan

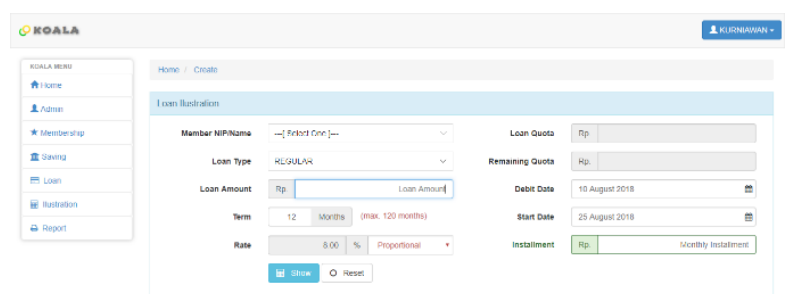

Gambar 11. Tampilan Halaman Apply New Loan

7. Halaman Report Payroll



Gambar 12. Tampilan Halaman Report Payroll

8. Halaman Report Saving 


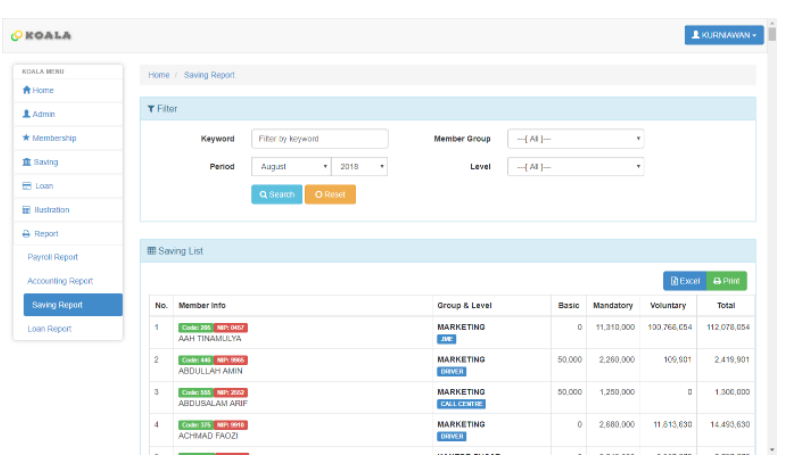

Gambar 13. Tampilan Halaman Report Saving

\section{c. Pengujian}

Menurut Larasati dan Masripah (2017:194) tidak menutup kemungkinan sebuah perangkat lunak mengalami perubahan ketika sudah dikirimkan ke user.

Dalam pengujian perangkat lunak ini penulis menggunakan suatu metode, metode yang diambil adalah metode pengujian Black Box. Menurut Suharyanto dan Najiyah (2017:83) Pengujian Black Box adalah pengujian yang sistemnya tanpa memperhatikan struktur logika perangkat

Tabel 1. Pengujian Halaman Login

\begin{tabular}{|c|c|c|c|c|c|}
\hline $\begin{array}{l}\mathrm{N} \\
\mathrm{O}\end{array}$ & $\begin{array}{l}\text { Skenario } \\
\text { Pengujia } \\
\mathrm{n}\end{array}$ & $\begin{array}{l}\text { Test } \\
\text { Case }\end{array}$ & $\begin{array}{l}\text { Hasil } \\
\text { yang di } \\
\text { harapka } \\
\mathrm{n}\end{array}$ & $\begin{array}{l}\text { Has } \\
\text { il } \\
\text { Uji }\end{array}$ & $\begin{array}{l}\text { Kesim } \\
\text { pulan }\end{array}$ \\
\hline 1 & $\begin{array}{l}\text { Mengos } \\
\text { ongkan } \\
\text { semua } \\
\text { isian } \\
\text { data } \\
\text { login } \\
\text { pada } \\
\text { login } \\
\text { admin } \\
\text { dan } \\
\text { langsung } \\
\text { klik } \\
\text { tombol } \\
\text { Login }\end{array}$ & $\begin{array}{l}\text { Usern } \\
\text { ame: } \\
\text { (Koso } \\
\text { ng) } \\
\text { Passw } \\
\text { ord: } \\
\text { (Koso } \\
\text { ng) }\end{array}$ & $\begin{array}{l}\text { Sistem } \\
\text { akan } \\
\text { menolak } \\
\text { akses } \\
\text { login. } \\
\text { Tampil } \\
\text { pesan } \\
\text { "Please } \\
\text { Fill Out } \\
\text { This } \\
\text { Field" } \\
\text { pada } \\
\text { kolom } \\
\text { usernam } \\
\text { e. }\end{array}$ & $\begin{array}{l}\text { Ses } \\
\text { uai } \\
\text { Har } \\
\text { apa } \\
\text { n }\end{array}$ & Valid \\
\hline 2 & $\begin{array}{l}\text { Hanya } \\
\text { mengisi } \\
\text { data } \\
\text { usernam } \\
\text { e dan } \\
\text { mengoso } \\
\text { ngkan } \\
\text { data } \\
\text { passwor } \\
\text { d, lalu }\end{array}$ & $\begin{array}{l}\text { Usern } \\
\text { ame: } \\
\text { (isi) } \\
\text { Passw } \\
\text { ord: } \\
\text { (koso } \\
\text { ng) }\end{array}$ & $\begin{array}{l}\text { Sistem } \\
\text { akan } \\
\text { menolak } \\
\text { akses } \\
\text { login. } \\
\text { Tampil } \\
\text { pesan } \\
\text { "Please } \\
\text { Fill Out } \\
\text { This }\end{array}$ & $\begin{array}{l}\text { Ses } \\
\text { uai } \\
\text { Har } \\
\text { apa } \\
\text { n }\end{array}$ & Valid \\
\hline
\end{tabular}

\begin{tabular}{|c|c|c|c|c|c|}
\hline & $\begin{array}{l}\text { klik } \\
\text { tombol } \\
\text { Login }\end{array}$ & & $\begin{array}{l}\text { Field“" } \\
\text { pada } \\
\text { kolom } \\
\text { passwor } \\
\text { d. }\end{array}$ & & \\
\hline 3 & $\begin{array}{l}\text { Hanya } \\
\text { mengisi } \\
\text { data } \\
\text { Passwor } \\
\text { d dan } \\
\text { mengoso } \\
\text { ngkan } \\
\text { data } \\
\text { usernam } \\
\text { e, lalu } \\
\text { klik } \\
\text { tombol } \\
\text { Sign in }\end{array}$ & $\begin{array}{l}\text { Usern } \\
\text { ame: } \\
\text { (Koso } \\
\text { ng) } \\
\text { Passw } \\
\text { ord: } \\
\text { (isi) }\end{array}$ & $\begin{array}{l}\text { Sistem } \\
\text { akan } \\
\text { menolak } \\
\text { akses } \\
\text { login. } \\
\text { Tampil } \\
\text { pesan } \\
\text { "Please } \\
\text { Fill Out } \\
\text { This } \\
\text { Field“" } \\
\text { pada } \\
\text { kolom } \\
\text { usernam } \\
\text { e. }\end{array}$ & $\begin{array}{l}\text { Ses } \\
\text { uai } \\
\text { Har } \\
\text { apa } \\
\text { n }\end{array}$ & Valid \\
\hline 4 & $\begin{array}{l}\text { Menginp } \\
\text { ut } \\
\text { dengan } \\
\text { kondisi } \\
\text { salah } \\
\text { satu data } \\
\text { benar } \\
\text { dan satu } \\
\text { lagi } \\
\text { salah } \\
\text { dan } \\
\text { langsung } \\
\text { klik } \\
\text { tombol } \\
\text { Login }\end{array}$ & $\begin{array}{l}\text { Usern } \\
\text { ame: } \\
\text { (bena } \\
\text { r) } \\
\text { Passw } \\
\text { ord: } \\
\text { (salah } \\
\text { ) }\end{array}$ & $\begin{array}{l}\text { Sistem } \\
\text { akan } \\
\text { menolak } \\
\text { akses } \\
\text { login. } \\
\text { Tampil } \\
\text { pesan } \\
\text { "Login } \\
\text { Failed, } \\
\text { passwor } \\
\text { d } \\
\text { provided } \\
\text { is } \\
\text { incorrect } \\
\text { !“ }\end{array}$ & $\begin{array}{l}\text { Ses } \\
\text { uai } \\
\text { Har } \\
\text { apa } \\
\text { n }\end{array}$ & Valid \\
\hline 5 & $\begin{array}{l}\text { Menginp } \\
\text { ut data } \\
\text { login } \\
\text { yang } \\
\text { benar, } \\
\text { lalu } \\
\text { nengklik } \\
\text { tombol } \\
\text { Sign in }\end{array}$ & $\begin{array}{l}\text { Usern } \\
\text { ame: } \\
\text { (bena } \\
\text { r) } \\
\text { Passw } \\
\text { ord: } \\
\text { (bena } \\
\text { r) }\end{array}$ & $\begin{array}{l}\text { Sistem } \\
\text { menerim } \\
\text { a akses } \\
\text { login } \\
\text { dan } \\
\text { langsun } \\
\mathrm{g} \\
\text { menamp } \\
\text { ilkan } \\
\text { halaman } \\
\text { Beranda }\end{array}$ & $\begin{array}{l}\text { Ses } \\
\text { uai } \\
\text { har } \\
\text { apa } \\
\text { n }\end{array}$ & Valid \\
\hline
\end{tabular}

Tabel 2. Pengujian Tambah Data Keanggotaan

\begin{tabular}{llllll}
\hline $\mathrm{N}$ & Skenar & Test & Hasil & Hasi & Kesim \\
o & io & Case & yang di \\
Penguj & & harapkan & & pulan \\
ian & & & & \\
\hline
\end{tabular}




\begin{tabular}{|c|c|c|c|c|c|}
\hline 1 & $\begin{array}{l}\text { Semua } \\
\text { field } \\
\text { tidak } \\
\text { terisi } \\
\text { kemud } \\
\text { ian } \\
\text { klik } \\
\text { simpan }\end{array}$ & $\begin{array}{l}\text { Field: } \\
\text { (koso } \\
\text { ng) }\end{array}$ & $\begin{array}{l}\text { Simpan } \\
\text { gagal dan } \\
\text { muncul } \\
\text { peringata } \\
n \\
\text { "Membe } \\
\text { r NIP is } \\
\text { invalid! " }\end{array}$ & $\begin{array}{l}\text { Sesu } \\
\text { ai } \\
\text { Hara } \\
\text { pan }\end{array}$ & Valid \\
\hline 2 & $\begin{array}{l}\text { Hanya } \\
\text { mengis } \\
\text { i } \\
\text { Memb } \\
\text { er NIP } \\
\text { tanpa } \\
\text { melak } \\
\text { ukan } \\
\text { inquiry } \\
\text { Memb } \\
\text { er } \\
\text { Inform } \\
\text { ation }\end{array}$ & $\begin{array}{l}\text { NIP: } \\
\text { (isi) } \\
\text { Lainn } \\
\text { ya: } \\
\text { (koso } \\
\text { ng) }\end{array}$ & $\begin{array}{l}\text { Simpan } \\
\text { gagal dan } \\
\text { muncul } \\
\text { peringata } \\
\mathrm{n} \\
\text { "Membe } \\
\text { r Code is } \\
\text { invalid!“" }\end{array}$ & $\begin{array}{l}\text { Sesu } \\
\text { ai } \\
\text { Hara } \\
\text { pan }\end{array}$ & Valid \\
\hline 3 & $\begin{array}{l}\text { Mengi } \\
\text { si } \\
\text { Memb } \\
\text { er NIP, } \\
\text { kemud } \\
\text { ian } \\
\text { melak } \\
\text { ukan } \\
\text { inquiry } \\
\text {. Kolom } \\
\text { lain di } \\
\text { kosong } \\
\text { kan. }\end{array}$ & $\begin{array}{l}\text { NIP: } \\
\text { (isi) } \\
\text { Teka } \\
\mathrm{n} \\
\text { Inquir } \\
\text { y } \\
\text { Field } \\
\text { lain: } \\
\text { (koso } \\
\text { ng) }\end{array}$ & $\begin{array}{l}\text { Simpan } \\
\text { gagal dan } \\
\text { muncul } \\
\text { peringata } \\
\mathrm{n} \\
\text { "Membe } \\
\text { r Code is } \\
\text { invalid!“" }\end{array}$ & $\begin{array}{l}\text { Sesu } \\
\text { ai } \\
\text { Hara } \\
\text { pan }\end{array}$ & Valid \\
\hline 4 & $\begin{array}{l}\text { Mengi } \\
\text { si } \\
\text { Memb } \\
\text { er NIP, } \\
\text { kemud } \\
\text { ian } \\
\text { melak } \\
\text { ukan } \\
\text { inquiry } \\
\text {, lalu } \\
\text { genera } \\
\text { te kode } \\
\text { anggot } \\
\text { a baru. } \\
\text { Lainny } \\
\text { a di } \\
\text { kosong } \\
\text { kan }\end{array}$ & $\begin{array}{l}\text { NIP: } \\
\text { (isi) } \\
\text { Teka } \\
\mathrm{n} \\
\text { Inquir } \\
\mathrm{y} \\
\text { Teka } \\
\mathrm{n} \\
\text { Gener } \\
\text { ate } \\
\text { Field } \\
\text { lain: } \\
\text { (koso } \\
\text { ng) }\end{array}$ & $\begin{array}{l}\text { Simpan } \\
\text { gagal dan } \\
\text { muncul } \\
\text { peringata } \\
\mathrm{n} \\
\text { "Membe } \\
\mathrm{r} \text { Group } \\
\text { is } \\
\text { invalid!“" }\end{array}$ & $\begin{array}{l}\text { Sesu } \\
\text { ai } \\
\text { Hara } \\
\text { pan }\end{array}$ & Valid \\
\hline
\end{tabular}

\begin{tabular}{|c|c|c|c|c|c|}
\hline 5 & $\begin{array}{l}\text { Mengi } \\
\text { si } \\
\text { Memb } \\
\text { er NIP, } \\
\text { kemud } \\
\text { ian } \\
\text { melak } \\
\text { ukan } \\
\text { inquiry } \\
, \quad \text { lalu } \\
\text { genera } \\
\text { te kode } \\
\text { anggot } \\
\text { a baru, } \\
\text { memili } \\
\text { h } \\
\text { group } \\
\text { anggot } \\
\text { a. } \\
\text { Lainny } \\
\text { a di } \\
\text { kosong } \\
\text { kan }\end{array}$ & $\begin{array}{l}\text { NIP: } \\
\text { (isi) } \\
\text { Teka } \\
\mathrm{n} \\
\text { Inquir } \\
\mathrm{y} \\
\text { Teka } \\
\mathrm{n} \\
\text { Gener } \\
\text { ate } \\
\text { Pilih } \\
\text { Grou } \\
\mathrm{p} \\
\text { Field } \\
\text { lain: } \\
\text { (koso } \\
\text { ng) }\end{array}$ & $\begin{array}{l}\text { Sistem } \\
\text { menerim } \\
\text { a akses } \\
\text { login dan } \\
\text { langsung } \\
\text { menampi } \\
\text { lkan } \\
\text { halaman } \\
\text { Home/B } \\
\text { eranda. }\end{array}$ & $\begin{array}{l}\text { Sesu } \\
\text { ai } \\
\text { hara } \\
\text { pan }\end{array}$ & Valid \\
\hline 6 & $\begin{array}{l}\text { Mengi } \\
\text { si } \\
\text { Memb } \\
\text { er NIP, } \\
\text { kemud } \\
\text { ian } \\
\text { melak } \\
\text { ukan } \\
\text { inquiry } \\
, \quad \text { lalu } \\
\text { genera } \\
\text { te kode } \\
\text { anggot } \\
\text { a baru, } \\
\text { memili } \\
\text { h } \\
\text { group } \\
\text { anggot } \\
\text { a, } \\
\text { inform } \\
\text { asi } \\
\text { rekeni } \\
\text { ng di } \\
\text { isi }\end{array}$ & $\begin{array}{l}\text { NIP: } \\
\text { (isi) } \\
\text { Teka } \\
\mathrm{n} \\
\text { Inquir } \\
\mathrm{y} \\
\text { Teka } \\
\mathrm{n} \\
\text { Gener } \\
\text { ate } \\
\text { Pilih } \\
\text { Grou } \\
\mathrm{p} \\
\text { Reke } \\
\text { ning: } \\
\text { (isi) }\end{array}$ & $\begin{array}{l}\text { Sistem } \\
\text { melakuk } \\
\text { an } \\
\text { simpan } \\
\text { data, } \\
\text { muncul } \\
\text { pesan } \\
\text { "Saving } \\
\text { members } \\
\text { hip } \\
\text { succeede } \\
\text { d..." dan } \\
\text { penggun } \\
\text { a akan } \\
\text { dialihkan } \\
\text { ke daftar } \\
\text { anggota. }\end{array}$ & $\begin{array}{l}\text { Sesu } \\
\text { ai } \\
\text { hara } \\
\text { pan }\end{array}$ & Valid \\
\hline
\end{tabular}

\section{d. Kode (Code / Coding)}

Dalam pembuatan aplikasi sistem koperasi berbasis web ini penulis menggunakan bahasa pemrograman C\# .Net, Javascript, CSS, HTML dan program Microsoft Visual Studio 2012 sebagai antarmuka grafis nya. Untuk basisdata yang digunakan penulis memakai Microsoft SQL Server 2012.

Menurut Puspitasari (2016:188) dalam Jurnal Pilar Nusa Mandiri, Basis data merupakan kumpulan dari 
item data yang saling berhubungan satu dengan yang lainnya yang diorganisasikan berdasarkan sebuah skema atau struktur tertentu, tersimpan di hardware komputer dan dengan software untuk melakukan manipulasi untuk kegunaan tertentu.

\section{e. Support}

Spesifikasi Hardware dan Software

\begin{tabular}{ll}
\hline \multicolumn{1}{c}{ Kebutuhan } & \multicolumn{1}{c}{ Keterangan } \\
\hline $\begin{array}{l}\text { Sistem } \\
\text { Operasi }\end{array}$ & Windows 10 \\
\hline Processor & Intel ${ }^{\circledR}$ Core ${ }^{\mathrm{TM}}$ I5 CPU 2.27 GHz \\
\hline Ram & $8.00 \mathrm{~GB}$ \\
\hline Hardisk & 256 GB \\
\hline Monitor & SVGA 14” \\
\hline Keyboard & 108 Key \\
\hline Printer & HP Deskjet 2135 \\
\hline Mouse & Standard \\
\hline Software & Microsoft Visual Studio 2012, \\
& Microsoft SQL Server 2012 \\
\hline
\end{tabular}

\section{KESIMPULAN}

Berdasarkan penelitian dan identifikasi masalah yang terdapat pada Sistem Koperasi IKITAMA, maka penulis dapat mengambil kesimpulan dari permasalahan yang ada sebagai berikut :

1. Sistem berjalan pada Koperasi IKITAMA saat ini masih kurang optimal, banyak data lost, redudansi data, pengarsipan masih menggunakan kertas, dan sering terjadi salah perhitungan, dengan dirancangnya sistem informasi koperasi ini akan memudahkan semua pihak terkait proses sistem yang berjalan.

2. Proses simpan pinjam belum efisien karena pengerjaannya yang belum by sistem, manual, prosedur yang panjang dan memakan waktu, serta keakuratan maupun kecepatan dalam pembuatan laporan masih kurang efektif, karena pengolahan data tersebut masih menggunakan Microsoft Excel.

3. Menerapkan sistem informasi koperasi dengan menggunakan bahasa pemrograman Microsoft C\#.NET MVC dan menggunakan MS SQL Server untuk basis datanya. Sistem Informasi ini memiliki kemampuan untuk mengurangi kesalahan pada segala aktifitas yang ada pada Koperasi IKITAMA

\section{REFERENSI}

Larasati, H., \& Masripah, S. (2017). Analisa Dan Perancangan Sistem Informasi Pembelian Grc Dengan Metode Waterfall. Jurnal Pilar Nusa Mandiri, 13(2), 193-198

Mentri/sekretaris negara Republik Indonesia. (1992). Undang-Undang Republik Indonesia Nomor 25 Tahun 1992 Tentang Perkoperasian. Lambaran Negara Republik Indonesia, 13.

Puspitasari, D. (2016). Rancang Bangun Sistem Informasi Koperasi Simpan Pinjam Karyawan Berbasis Web. Jurnal Pilar Nusa Mandiri, 11(2), 186-196.

Suharyanto. (2017). Kajian kesuksesan e-commerce (studi kasus: darulhaq.com). Jurnal Ilmu Pengetahuan Dan Teknologi Komputer, 2(2), 139-145.

Sukamto, R. A., \& Shalahuddin, M. (2016). Rekayasa Perangkat Lunak (Terstruktur dan berbasis objek). Sdlc, 4, 133-173.

Sukamto, R. A., \& Shalahuddin, M. (2016). Rekayasa Perangkat Lunak. UML (Unified Modeling Language), 4, 133-171.

\section{PROFIL PENULIS}

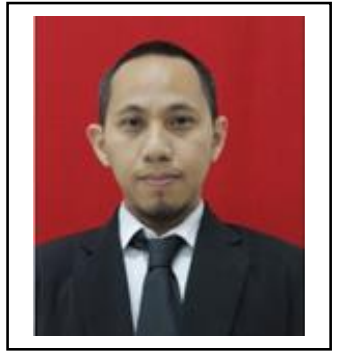

\section{Kurniawan Prasetyo, S.KOM.}

Lahir di Jakarta, tahun 1982, Saat ini bekerja sebagai System Analyst dan Senior Programmer pada perusahaan Asuran Jiwa PT. Indolife Pensiontama, mengawali karir sebagai seorang Junior Programmer sejak tahun 2008.

\section{Suharyanto, M.Kom.}

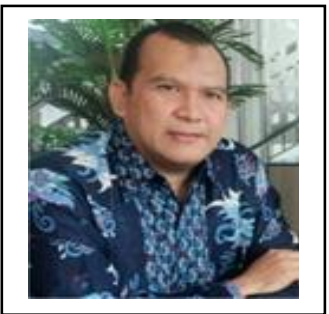

Lahir di Jakarta, tahun 1974, Staff pengajar pada Universitas BSI Jakarta. Sampai saat ini masih aktif mengajar, sangat menyukai bidang ecommerce banyak memberikan bimbingan kepada mahasiswa terkait aplikasi bisnis ecommerce. 